\title{
Comparative efficacy of different estrus synchronization protocols on estrus induction response, fertility and plasma progesterone and biochemical profile in crossbred anestrus cows
}

\author{
A. J. Dhami, B. B. Nakrani, K. K. Hadiya, J. A. Patel and R. G. Shah \\ Department of Animal Reproduction, Gynaecology and Obstetrics, College of Veterinary Science and Animal Husbandry, \\ Anand Agricultural University, Anand-388 001, Gujarat, India. \\ Corresponding author: A. J. Dhami, e-mail: ajdhami@aau.in, BBN: bhaveshnakrani@sagbidaj.org, \\ KKH: kamleshhadiya@yahoo.co.in, JAP: japatel@aau.in, RGS: rohitshah_44@yahoo.co.in \\ Received: 15-06-2015, Revised: 24-09-2015, Accepted: 05-10-2015, Published online: 21-11-2015
}

doi: 10.14202/vetworld.2015.1310-1316 How to cite this article: Dhami AJ, Nakrani BB, Hadiya KK, Patel JA, Shah RG (2015) Comparative efficacy of different estrus synchronization protocols on estrus induction response, fertility and plasma progesterone and biochemical profile in crossbred anestrus cows, Veterinary World 8(11): 1310-1316.

\begin{abstract}
Aim: To evaluate estrus induction response and fertility including plasma progesterone and biochemical profile following use of three standard hormonal protocols in anestrus crossbred cows.

Materials and Methods: The study was carried out on 40 true anestrus and 10 normal cyclic cows. 10 anestrus cows each were treated with standard intravaginal controlled internal drug release (CIDR) device, Ovsynch (GPG) protocol, and Norgestomet ear implant with fixed-time artificial insemination (FTAI). 10 anestrus cows were kept as untreated control while 10 cows exhibiting the first estrus within 90 days postpartum without any treatment served as normal cyclic control. Blood samples were obtained from treated cows on day 0, 7, 9 (AI) of treatment and day 21 post-AI, and from control groups on the day of AI and day 21 post-AI for estimation of plasma progesterone, protein, cholesterol, calcium, and inorganic phosphorus profile.

Results: The use of CIDR, Ovsynch, and Norgestomet ear implant protocols resulted in 100\% estrus induction with conception rates at induced estrus of $60 \%, 50 \%$, and $50 \%$, and the overall of three cycles as $80 \%, 80 \%$, and $70 \%$. In untreated anestrus control $(\mathrm{n}=10)$, only three cows exhibited spontaneous estrus within 90 days of follow-up and conceived giving the first service and overall conception rates of $66.66 \%$ and $30.00 \%$, respectively. In normal cyclic control ( $\mathrm{n}=10$ ), the conception rates at first and overall of three cycles were $50 \%$ and $80 \%$. The overall mean plasma progesterone $\left(\mathrm{P}_{4}\right)$ concentrations in anestrus cows studied on day 0 (initiation), 7 (prostaglandin injection and/or removal of implant), 9 (FTAI) of treatment and on day 21 post-AI revealed that the values on day 7 and 21 were significantly $(p<0.01)$ higher than other two periods in all three groups. The concentrations were significantly $(\mathrm{p}<0.05)$ higher in conceived than non-conceived group on day 21 post-AI in CIDR ( $4.36 \pm 0.12$ vs. $1.65 \pm 0.82 \mathrm{ng} / \mathrm{ml})$ and Ovsynch $(4.85 \pm 0.62 \mathrm{vs} .1 .59 \pm 0.34 \mathrm{ng} / \mathrm{ml})$, but not in Norgestomet ear implant $(4.50 \pm 0.53$ vs. $3.02 \pm 1.15 \mathrm{ng} / \mathrm{ml})$ or normal cyclic group $(5.39 \pm 0.67 \mathrm{vs} .3 .13 \pm 0.37 \mathrm{ng} / \mathrm{ml})$. The cholesterol and protein levels were significantly higher, but not the calcium and phosphorus, in normal cyclic control than in anestrus groups. The influence of treatment days and pregnancy status was not significant for any of the biochemical constituents in any of the groups.
\end{abstract}

Conclusion: Ovsynch and/or CIDR synchronization protocol can be effectively used to improve fertility up to $80 \%$ in anestrus cows, as compared to $30 \%$ in anestrus control, combined with plasma progesterone to delineate the reproductive status before and after treatment.

Keywords: anestrus, conception rate, cow, estrus induction, fertile estrus induction interval,treatment protocols.

\section{Introduction}

Genetic upgradation of indigenous cattle population through crossbreeding is the only immediate approach to meet the challenges of milk production demand in India. The optimum reproductive efficiency of these animals is equally important for economic productivity. Infertility is one of the pathological conditions qualified as disease of production. It is widespread in modern farming, especially in crossbred animals. Infertility negatively affects productivity and return on investment of the farmers. Anestrus forms the major condition constituting about $2 / 3^{\text {rd }}$ of

Copyright: The authors. This article is an open access article licensed under the terms of the Creative Commons Attributin License (http:// creative commons.org/licenses/by/2.0) which permits unrestricted use, distribution and reproduction in any medium, provided the work is properly cited. the infertility problems in crossbred cattle [1]. Various hormonal preparations and protocols are being practiced by the field veterinarians to treat postpartum anestrus, the most prevalent reproductive problem, in dairy animals, but the results are inconsistent [2-4]. Hormonal therapies have good therapeutic value to enhance reproductive efficacy in infertile animals only with good nutritional status $[2,3,5]$. The variable results obtained following hormonal treatments by different workers may be largely due to nutritional status, faulty management, ovarian changes, endocrine events, and even uterine infection. Use of hormonal protocols like Ovsynch, controlled internal drug release (CIDR) device and Norgestomet ear implant can be helpful in inducing and synchronizing estrus and getting better conception rate in anestrus dairy bovines with lesser 
number of services per conception and making acyclic ones to cycle normally, thereby achieving ideal inter-calving interval of 12-13 months $[1,2,6]$.

The progesterone hormone is responsible for stimulation of cyclicity, follicular development and also for maintenance of pregnancy.The plasma protein, cholesterol and minerals profile denote the nutritional status of animals and are related with their fertility [5,7]. The cholesterol being precursor of steroid hormones play an important role in steroidogenesis; while calcium tones up the genitalia, and protein and inorganic phosphorus are involved at the cellular level in metabolic processes. These hormonal and nutritional profiles are being disturbed by many metabolic and environmental factors and hamper normal physiology of the animal body [7].

The comparative studies involving the use of different estrus induction/synchronization protocols at a time under an identical environment in crossbred cows are, however, meager and are mostly based on clinical response only without plasma progesterone or biochemical evaluation [7-9]. Hence, this study was planned to evaluate the comparative efficacy of CIDR, Ovsynch and Norgestomet ear implant protocols in anestrus crossbred cows under field conditions in terms of estrus induction response, fertility enhancement, and their influence on plasma progesterone and biochemical profile.

\section{Materials and Methods}

\section{Ethical approval}

The prior approval from the Institutional Animal Ethics Committee was obtained for use of farmers animals in this study.

\section{Selection and treatment of animals}

This study was carried out during November, 2013 to March, 2014 under middle Gujarat agro-climatic condition. 40 postpartum ( $>90$ days) anestrus crossbred cows and 10 normal cyclic cows of the average body condition score were selected from villages of Amul and Panchamrut milk-shed areas of Gujarat. The cows were screened gynaeco-clinically for their reproductive status. Detailed history and rectal palpation findings were recorded. Anestrus cows were confirmed by palpating small smooth inactive ovaries per rectum twice 10 days apart. All the selected cows were dewormed using ivermectin, $100 \mathrm{mg} \mathrm{S} / \mathrm{C}$ and were supplied with multi-mineral boluses one bolus daily for 7 days. They were randomly subjected to following three estrus induction/synchronization protocols (viz., CIDR, Ovsynch and Norgestomet ear implant, $n=10$ each) with fix-timed artificial insemination (FTAI) $[2,5,7,10]$.

\section{Treatment protocols}

In 10 true anestrus crossbred cows, CIDR (1.38 g of progesterone in the silastic coil, Pfizer Animal Health, Mumbai) was inserted intravaginally on day 0 . It was removed on day 7 together with I/M injection of prostaglandin $\mathrm{F} 2 \alpha\left(\mathrm{PGF}_{2} \alpha\right) 25 \mathrm{mg}$ (dinoprost tromethamine,). Injection GnRH $10 \mu \mathrm{g}$ (buserelin acetate,) was administered I/M on day 9 and FTAIs were performed twice on day 9 and 10, as shown in Figure-1.

10 true anestrus cows under Ovsynch protocol were administered intramuscularly with injection buserelin acetate - $\mathrm{GnRH} 20 \mu \mathrm{g}$ on day 0 , injection $\mathrm{PGF}_{2} \alpha$ $25 \mathrm{mg}$ on day 7, and second injection of GnRH $10 \mu \mathrm{g}$ on day 9 followed by FTAIs twice on day 9 and 10 (Figure-2).

In another group of 10 anestrus cows, crestar implant (containing $3.3 \mathrm{mg}$ norgestomet, Intervet India Pvt. Ltd.) was inserted $\mathrm{S} / \mathrm{C}$ in the outer face of the ear-base together with $2 \mathrm{ml}$ Crestar injection $\mathrm{I} / \mathrm{M}$ (injection containing $3 \mathrm{mg}$ norgestomet and $5 \mathrm{mg}$ estradiol valerate) on day 0 . The implant was removed on day 7 together with $\mathrm{I} / \mathrm{M}$ injection of $25 \mathrm{mg} \mathrm{PGF}_{2} \alpha$ dinoprost tromethamine and injection buserelin acetate $10 \mu \mathrm{g}$ I/M was given on day 9 followed by FTAIs twice at 0 and $24 \mathrm{~h}$ later (Figure-3). Signs of estrus and rectal palpation findings were recorded for animals of all the groups at AI.

Another 10 anestrus cows were kept as anestrus control without hormone therapy and 10 normal cyclic cows that expressed spontaneous estrus within 90 days postpartum and inseminated served as normal cyclic control group. Cows in spontaneous or induced estrus were inseminated using good quality frozen-thawed semen. Animals detected in estrus subsequent to FTAI were re-inseminated up to two cycles and in non-return cases pregnancy was confirmed rectum 60 days of last AI.

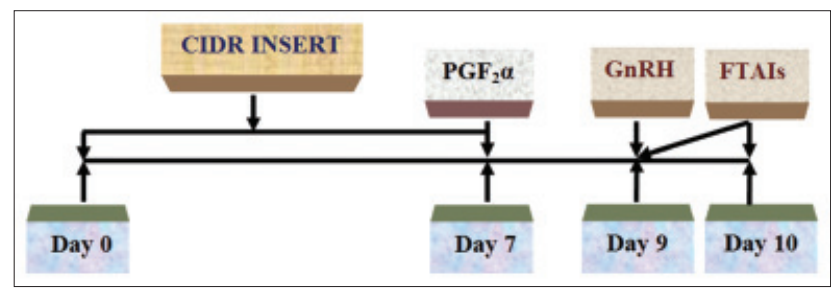

Figure-1: CIDR protocol of estrus synchronization.

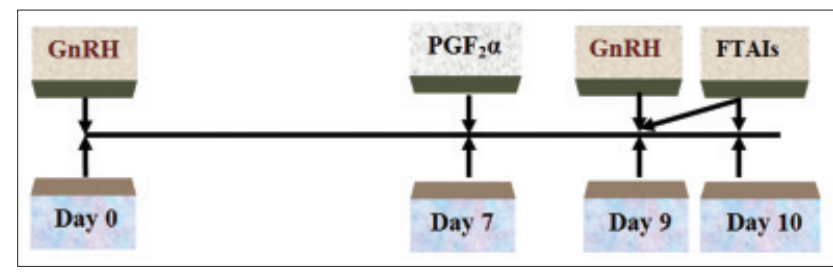

Figure-2: Ovsynch protocol of estrus synchronization.

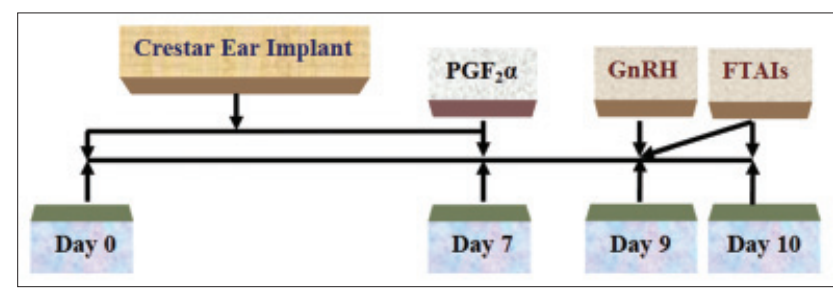

Figure-3: Norgestomet ear implant protocol of estrus synchronization. 


\section{Blood sampling}

All the hormonally treated/untreated true anestrus and normal cyclic cows were studied for their reproductive status and plasma progesterone and biochemical profile. For this, jugular blood samples were collected in heparinized vacutainers 4 times from true anestrus animals, i.e., on day 0 - just before treatment (on diagnosis), on day 7 - at the time of $\mathrm{PGF}_{2} \alpha$ administration, on day 9 - induced estrus/FTAI (FTAI done twice $24 \mathrm{~h}$ apart, i.e., on day 9 and 10 after initiation of treatment) and on day 21 post-AI. Blood sampling for control groups was done on the day of spontaneous estrus if any, and on day 21 post-AI. The samples were centrifuged at $3000 \mathrm{rpm}$ for $15 \mathrm{~min}$ and plasma separated out was stored deep frozen at $-20^{\circ} \mathrm{C}$ with a drop of merthiolate $(0.1 \%)$ until analyzed.

\section{Plasma assay}

Plasma progesterone profile was estimated using the standard radio-immuno-assay (RIA) technique of Kubasic et al. [11]. Labeled antigen $\left(\mathrm{I}^{125}\right)$, antibody coated tubes and standards were procured from Immunotech, France. The sensitivity of the assay was $0.1 \mathrm{ng} / \mathrm{ml}$. The intra-and interassay coefficients of variation were $5.4 \%$ and $9.1 \%$, respectively. The concentrations of plasma total protein, total cholesterol, calcium and inorganic phosphorus were determined by standard procedures and assay kits procured from Analytical Technologies Pvt. Limited, Baroda, on chemistry analyzer.

\section{Statistical analysis}

The data on estrus response, conception rate (by Chi-square test) and plasma profiles of progesterone and biochemical constituents were analyzed statistically through analysis of variance [12] using online SAS software version 20.00 .

\section{Results and Discussion}

\section{Estrus induction and conception rates}

All the cows (100\%) under CIDR, Ovsynch, and Norgestomet ear implant protocols exhibited induced estrus with varying intensity similar to normal cyclic control group within $42-72 \mathrm{~h}$ from the time of $\mathrm{PGF}_{2} \alpha$ injection. The conception rates obtained at induced estrus in cows under these three protocols were $60.00 \%, 50.00 \%$, and $50.00 \%$, respectively, with corresponding overall pregnancy rates of three cycles as $80.00 \%, 80.00 \%$, and $70.00 \%$. Results were better with CIDR and Ovsynch protocols as compared to Norgestomet ear implant (Table-1). In untreated anestrus control group, only 3 out of 10 cows exhibited spontaneous estrus within 90 days of follow-up and two conceived at first AI (CR, 66.66\%) and third at $3^{\text {rd }} \mathrm{AI}$ giving overall pregnancy rate of only $30.00 \%$ $(3 / 10)$. In the normal cyclic control group $(n=10)$, the conception rates at the first cycle and overall of three cycles were $50.00 \%$ and $80.00 \%$, respectively, with mean service period of $98.77 \pm 6.84$ days (Table- 1 ).

Themean estrus induction intervals of $58.27 \pm 1.93$, $64.13 \pm 1.33$, and $54.00 \pm 1.17 \mathrm{~h}$ observed in cows under CIDR, Ovsynch and Norgestomet ear implant protocols compared favorably with the previous reports in anestrus cows $[7,13,14]$ and buffaloes $[3,5]$ using such types of protocols. Comparatively shorter interval was however reported by others [6] in heifers and multiparous cows. Chaudhari et al. [2] reported this interval to be much shorter as $25.41 \pm 0.94,21.95 \pm 0.20$ and $22.68 \pm 1.46$ h using Crestar, Crestar + 500 IU PMSG, and Crestar + Receptal in Kankrej heifers. Following removal of implant resumption of follicular development and maturation is due to the flux of the gonadotropin from the pituitary gland. Although behavioral estrus in case of Norgestomet ear implant was observed because of direct effect of both exogenously administered estradiol and the high endogenous estradiol on the hypothalamus [15].

The first service conception rate of $50.00 \%$ with Norgestomet ear implant in the present study is comparable with the earlier result of Nak et al. [6] as $41.40 \%$ in anestrus heifers. The findings with CIDR and Ovsynch protocols are also in line with Patel et al. [7] as 50.00\% and 30.00\% in anestrus crossbred cows, respectively, and Bhoraniya et al. [10]

Table-1: Effects of various estrus induction/synchronization protocols on estrus induction response, estrus induction intervals, and conception rates in anestrus crossbred cows.

\begin{tabular}{|c|c|c|c|c|c|c|c|c|}
\hline \multirow[t]{2}{*}{ Treatment groups } & \multirow[t]{2}{*}{ No. } & \multirow{2}{*}{$\begin{array}{c}\text { Estrus } \\
\text { induction } \\
\text { response } \\
(\%)\end{array}$} & \multirow{2}{*}{$\begin{array}{l}\text { PG injection } \\
\text { to estrus } \\
\text { interval } \\
\text { (h) }\end{array}$} & \multicolumn{4}{|c|}{ Conception rate $(\%)$} & \multirow{2}{*}{$\begin{array}{c}\text { PG injection } \\
\text { to fertile } \\
\text { estrus interval } \\
\text { (days) }\end{array}$} \\
\hline & & & & $\begin{array}{c}\text { Induced/ } \\
\text { first } \\
\text { estrus }\end{array}$ & $\begin{array}{l}\text { Second } \\
\text { cycle }\end{array}$ & $\begin{array}{l}\text { Third } \\
\text { cycle }\end{array}$ & $\begin{array}{l}\text { Overall } \\
\text { of three } \\
\text { cycles }\end{array}$ & \\
\hline CIDR & 10 & $\begin{array}{l}100.00 \\
(n=10)\end{array}$ & $58.27 \pm 1.93$ & $\begin{array}{l}60.00 \\
(6 / 10)\end{array}$ & $\begin{array}{l}25.00 \\
(1 / 4)\end{array}$ & $\begin{array}{l}33.33 \\
(1 / 3)\end{array}$ & $\begin{array}{l}80.00 \\
(8 / 10)\end{array}$ & $\begin{array}{c}12.44 \pm 3.86 \\
(n=8)\end{array}$ \\
\hline Ovsynch & 10 & $\begin{array}{l}100.00 \\
(n=10)\end{array}$ & $64.13 \pm 1.33$ & $\begin{array}{l}50.00 \\
(5 / 10)\end{array}$ & $\begin{array}{l}40.00 \\
(2 / 5)\end{array}$ & $\begin{array}{l}33.33 \\
(1 / 3)\end{array}$ & $\begin{array}{l}80.00 \\
(8 / 10)\end{array}$ & $\begin{array}{c}12.89 \pm 4.31 \\
(n=8)\end{array}$ \\
\hline Norgestomet ear implant & 10 & $\begin{array}{l}100.00 \\
(n=10)\end{array}$ & $54.00 \pm 1.17$ & $\begin{array}{l}50.00 \\
(5 / 10)\end{array}$ & $\begin{array}{l}20.00 \\
(1 / 5)\end{array}$ & $\begin{array}{l}25.00 \\
(1 / 4)\end{array}$ & $\begin{array}{l}70.00 \\
(7 / 10)\end{array}$ & $\begin{array}{c}11.78 \pm 3.81 \\
(n=7)\end{array}$ \\
\hline Untreated anestrus control & 10 & $\begin{array}{l}30.00 \\
(n=3)\end{array}$ & - & $\begin{array}{l}66.66 \\
(2 / 3)\end{array}$ & - & $\begin{array}{c}100.00 \\
(1 / 1)\end{array}$ & $\begin{array}{l}30.00 \\
(3 / 10)\end{array}$ & $\begin{array}{c}149.52 \pm 5.67 * \\
(n=3)\end{array}$ \\
\hline Normal cyclic control & 10 & $\begin{array}{l}100.00 \\
(n=10)\end{array}$ & - & $\begin{array}{l}50.00 \\
(5 / 10)\end{array}$ & $\begin{array}{l}40.00 \\
(2 / 5)\end{array}$ & $\begin{array}{l}33.33 \\
(1 / 3)\end{array}$ & $\begin{array}{l}80.00 \\
(8 / 10)\end{array}$ & $\begin{array}{c}98.77 \pm 6.84 * \\
(n=8)\end{array}$ \\
\hline
\end{tabular}

Figures in parentheses indicate number of animals/observations, *Service period/days open. PG=Prostaglandin, CIDR=Controlled internal drug release 
as $66.66 \%$ and $33.33 \%$ overall conception rate in anestrus Kankrej cows with same protocols. Ozyurtlu et al. [16] reported overall conception rates of $44.00 \%$ and $53.85 \%$ in Norgestomet and PRID groups, respectively, which are relatively lower than the present findings with Norgestomet ear implant and CIDR. Relatively inferior pregnancy rate as $33.33 \%$ was also reported by Chaudhari et al. [2] with Norgestomet ear implant. Lower first service conception rates of $40.00 \%$ and $30.00 \%$ [7], and $36.84 \%$ and $29.41 \%$ [9], respectively, with CIDR and Ovsynch protocols, are also documented by others.

With Ovsynch and Norgestomet ear implant, Nak et al. [6] reported overall conception rate of $42.18 \%$ and $29.60 \%$ in non-cycling cows and $44.07 \%$ and $41.4 \%$ for heifers. Martinez et al. [17] also reported that the addition of progestin to the Cosynch or Ovsynch regimen resulted in significantly improved pregnancy rates in heifers but not in cows. El-Zarkouny et al. [4] reported that anestrus dairy cow treated with Ovsynch plus CIDR had a higher pregnancy rate $(64 \%)$ than anestrus cows treated with Ovsynch alone (27\%). However, cycling cows receiving Ovsynch plus CIDR had a pregnancy rate similar to that of cycling cows receiving Ovsynch alone. Stevenson et al. [18] reported that pregnancy outcomes showed larger increases when cows were treated with Ovsynch plus CIDR than with Ovsynch alone because more anestrus cows conceived. However, our results showed similar results with CIDR and Ovsynch protocols but Norgestomet ear implant group showed less overall pregnancy outcomes than other two protocols. The reduced fertility at norgestomet induced estrus may be owing to the luteal dysfunction [19], which may be due to insufficient luteinizing hormone production following implant withdrawal [20]. Although better conception rate was obtained by Rentfrow et al. [13] in Synchro-Mate-B treated Brahman heifers (18.2\%) and Singh et al. [21] in anestrus heifers and cows (40\%).
Further, around $30 \%$ conception rates were obtained at the second and third cycle in anestrus cows induced to cycle, which is near to normal cycling cows (40\%and 33\%). This proved that all the protocols induced and synchronized the estrus and then established normal cyclicity in treated animals, resulting into conceptions in subsequent cycles like normal breeding cows. These observations further supported the previous observations on the use of similar protocols in anestrus cows and buffaloes by many workers $[2,7,9,10,15,22]$.

Thus, estrus could be induced in true anestrus cows within 2-3 days from the day of $\mathrm{PGF}_{2} \alpha$ injection in each protocol and made them pregnant within a period of 10-12 days (95-100 days postpartum) in comparison to $149.52 \pm 5.67$ days of service period recorded in untreated control group, indicating a huge curtailment (around 1.5-2.0 months) in the waiting period of anestrus animals to evince estrus and become pregnant. The pooled conception rates of three treatment protocols obtained $(76.66 \%)$ in anestrus cows indicated the positive contributory role of handling the problem of acyclicity in cows, nearly at par with normal cyclic control cows $(80.00 \%)$.

\section{Plasma progesterone profile}

The mean levels of plasma progesterone recorded on day $0,7,9$ (AI) of treatment and on day 21 post-AI in anestrus cows under CIDR, Ovsynch, and Norgestomet ear implant protocols, and on the day of AI and day 21 post-AI in the normal control group are presented in Table- 2 . The data show that the mean plasma progesterone $(\mathrm{ng} / \mathrm{ml})$ concentrations were low toward basal values on day 0 , i.e., on the day of initiation of treatment in all three groups, suggesting that the animals were in anestrus phase. These levels, subsequently, rose significantly $(\mathrm{p}<0.01)$ to the peak values on day $7(5.58 \pm 0.98,4.10 \pm 0.78$ and $1.92 \pm 0.23 \mathrm{ng} / \mathrm{ml})$, particularly in animals under CIDR and Ovsynch

Table-2: Plasma progesterone concentrations $(\mathrm{ng} / \mathrm{ml})$ in normal cyclic and anestrus cows on different days of treatment/ AI under various estrus induction protocols.

\begin{tabular}{llccccc}
\hline Treatment groups & Pregnancy & No. & \multicolumn{4}{c}{ Days from initiation of treatment/AI } \\
\cline { 4 - 7 } & status & & Day 0 & Day 7 & Day 9 (AI) & Day 21 post-AI \\
\hline CIDR & Conceived & 6 & $2.19 \pm 0.51$ & $5.88 \pm 1.27$ & $0.64 \pm 0.15$ & $4.36 \pm 0.12^{*}$ \\
& Non-conceived & 4 & $2.68 \pm 0.55$ & $5.13 \pm 1.81$ & $1.49 \pm 1.07$ & $1.65 \pm 0.82$ \\
Ovsynch & Overall & 10 & $2.38 \pm 0.36^{\mathrm{ab}}$ & $5.58 \pm 0.99^{\mathrm{c}}$ & $0.98 \pm 0.42^{\mathrm{a}}$ & $3.27 \pm 0.54^{\mathrm{b}}$ \\
& Conceived & 5 & $1.70 \pm 0.34$ & $4.98 \pm 0.96$ & $0.69 \pm 0.16$ & $4.85 \pm 0.62^{*}$ \\
& Non-conceived & 5 & $2.38 \pm 0.55$ & $3.22 \pm 1.18$ & $1.60 \pm 0.34$ & $1.59 \pm 0.34$ \\
Norgestomet ear implant & Cverall & 10 & $2.04 \pm 0.33^{\mathrm{ab}}$ & $4.10 \pm 0.78^{\mathrm{c}}$ & $1.14 \pm 0.23^{\mathrm{a}}$ & $3.22 \pm 0.64^{\mathrm{bc}}$ \\
& Conceived & 5 & $1.68 \pm 0.29$ & $1.93 \pm 0.35$ & $0.60 \pm 0.08$ & $4.50 \pm 0.53$ \\
& Non-conceived & 5 & $1.23 \pm 0.22$ & $1.91 \pm 0.33$ & $0.83 \pm 0.23$ & $3.02 \pm 1.15$ \\
Normal cyclic control & Overall & 10 & $1.45 \pm 0.19^{\mathrm{ab}}$ & $1.92 \pm 0.23^{\mathrm{b}}$ & $0.72 \pm 0.12^{\mathrm{a}}$ & $3.76 \pm 0.65^{\mathrm{c}}$ \\
& Conceived & 4 & - & - & $0.57 \pm 0.34$ & $5.39 \pm 0.67$ \\
& Non-conceived & 6 & - & - & $0.35 \pm 0.23$ & $3.13 \pm 0.37$ \\
& Overall & 10 & - & - & $0.43 \pm 0.17^{\mathrm{a}}$ & $4.98 \pm 0.45^{\mathrm{b}}$ \\
\hline
\end{tabular}

$* p<0.05$; Means bearing uncommon superscripts within the row/column differ significantly $(p<0.05)$. Day $0=$ Day of starting the treatment, Day 7=Administration of PG, Day 9=Fixed time AI, Day 21=Day 21 post-AI. Blood profile of untreated control cows is not shown in table due to only small number conceived (2 out of 10) in that group. $P G=$ Prostaglandin, $A I=$ Artificial insemination 
protocols, i.e. just before implants were removed and $\mathrm{PGF}_{2} \alpha$ was injected. Thereafter, the mean progesterone levels dropped suddenly and significantly within $48 \mathrm{~h}$ of $\mathrm{PGF}_{2} \alpha$ injection and/or implant removal to the basal values coincident to induced estrus when FTAIs were done. These levels again increased significantly $(\mathrm{p}<0.01)$ on day 21 post-AI in all the groups $(3.27 \pm 0.54,3.22 \pm 0.64$, and $3.76 \pm 0.65 \mathrm{ng} / \mathrm{ml})$ due to estruses being ovulatory with development and maintenance of corpus luteum (CL) and the establishment of pregnancy in some animals. In normal cyclic control group also the mean plasma progesterone concentration was the lowest $(0.43 \pm 0.17 \mathrm{ng} / \mathrm{ml})$ on the day of spontaneous estrus/AI, which rose significantly $(\mathrm{p}<0.05)$ on day 21 post-AI $(4.98 \pm 0.45 \mathrm{ng} / \mathrm{ml})$ due to the establishment of pregnancy in four cows in that cycle.

The mean plasma progesterone concentrations in conceived and non-conceived groups in all three treatment protocols and in normal cyclic control group were found to be statistically similar on day 0,7 and even on day 9 (AI), but on day 21 post-AI, the conceived cows had significantly higher mean plasma progesterone concentrations as compared to non-conceived ones only in CIDR $(4.36 \pm 0.12$ vs. $1.65 \pm 0.82 \mathrm{ng} / \mathrm{ml})$ and Ovsynch $(4.85 \pm 0.62$ vs. $1.59 \pm 0.34 \mathrm{ng} / \mathrm{ml})$ protocols (Table-2). These findings on plasma progesterone profile with respect to effect of CIDR and Ovsynch protocols and/or in normal cyclic group closely corroborated with the earlier observations in anestrus cows $[7,9,10]$ and in anestrus buffaloes $[3,5,23]$ under such protocols. The levels of plasma $\mathrm{P}_{4}$ on the day of beginning of treatment protocol helped delineate the reproductive and endocrine status of the animals and thereby predicting the possible response to the therapy. The higher plasma $\mathrm{P}_{4}$ recorded on day 21 post-AI in conceived cows of all the groups was due to establishment of pregnancy and maintenance of CL function, while significantly low yet variable plasma $\mathrm{P}_{4}$ noted on day 21 post-AI in non-conceived cows could be due to their return to next estrus at varying intervals on account of probable irregular or long cycle length, early embryonic mortality after day 17 or uncoordinated, unexplained hormonal changes in some of them. These findings corroborated with the observation of Nakrani et al. [5] using same three protocols in buffaloes and of Ayad et al.[24] using Norgestomet ear implant in cattle.

The mean plasma progesterone levels obtained on the day of initiation of CIDR and Ovsynch treatments in the present study corroborated with the earlier findings in zebu and crossbred cows [7,9,10,25]. Significant rise observed in plasma $\mathrm{P}_{4}$ profile on day 7 of treatments in the present study with CIDR and Ovsynch protocols $(4.97 \pm 1.68$ and $3.75 \pm 0.47 \mathrm{ng} / \mathrm{ml})$ over initial ( 0 day) values, with sudden drop to almost basal values on induced estrus within 48-60 h after PG injection (Table-2), has also been reported earlier in anestrus cows $[9,10,22]$ by employing CIDR and Ovsynch protocol. The apparently higher mean levels of progesterone found on day 21 post-AI in non-conceived cows covered under Norgestomet ear implant protocol and normal control group (3.02 \pm 1.15 and $3.13 \pm 0.37 \mathrm{ng} / \mathrm{ml}$, respectively) are suggestive of possibility of either prolonged cycles due to extended luteal phase/delayed luteal regression and/or delayed embryonic death. Significantly higher mean plasma progesterone level $(5.58 \pm 0.99 \mathrm{ng} / \mathrm{ml})$ recorded on day 7 in CIDR group might be due to the continuous release of the exogenous progesterone from the progesterone molded silastic coil inserted in the anterior vagina of the cows. In the Ovsynch protocol the rise in mean progesterone level $(4.10 \pm 0.78 \mathrm{ng} / \mathrm{ml})$ noted on day 7 might be due to luteinization of some of the growing follicles and/or ovulation of dominant follicle and formation of accessory CL under the influence of $\mathrm{GnRH}$, simulating diestrum phase, while in the Norgestomet ear implant protocol the mean plasma progesterone level $(1.92 \pm 0.23 \mathrm{ng} / \mathrm{ml})$ did not show rise in the value probably due to presence of synthetic progestagen in that implant, which is not detected by $17 \alpha$-hydroxyprogesterone RIA.

\section{Biochemical and mineral profile}

The results of biochemical analysis did not reveal significant variations in plasma total cholesterol, total protein, calcium, and inorganic phosphorus profiles between days and periods of the treatment in any of the groups or between conceived and non-conceived cows. Although the cholesterol concentration was non-significantly higher, and protein was lower in conceived as compared to non-conceived cows. However, the pooled values of cholesterol and protein were significantly higher in normal cyclic cows than in anestrus cows of CIDR and Ovsynch groups (Table-3). Similar results of cholesterol and protein were observed in anestrus cows and buffaloes by earlier researchers $[7,26]$. However, others [27] reported that the conceiving cows and buffaloes had significantly higher levels of plasma cholesterol and protein as compared to non-conceiving ones. Earlier the higher mean plasma total cholesterol levels at induced estrus and $22^{\text {nd }}$ day post-AI than that of pre-treatment level in GnRH treated anestrus buffaloes have been documented [28], and the high level of cholesterol increased the estrogen synthesis resulting in manifestation of heat [28]. The higher levels of cholesterol in cyclic as compared to acyclic cows and buffaloes are however also reported by previous workers [7,29,30]. Patel et al. [7] in crossbred cows, Ramakrishnan et al. [25] in Gir cows, and Nakrani et al. [5] and Savalia et al. [26] in buffaloes,however, recorded significantly higher total protein in conceived than non-conceived and in cyclic than anestrus animals. Gentile et al. [31] opined that serum protein level was not related with fertility in dairy cows. However, as has been noted in the present study Patel et al. [7] also opined that the crossbred cows having 
Table-3: Mean values of plasma protein, cholesterol, calcium and phosphorus concentrations in normal cyclic and anestrus cows under various estrus induction protocols.

\begin{tabular}{|c|c|c|c|c|c|c|c|}
\hline \multirow{2}{*}{$\begin{array}{l}\text { Reproductive } \\
\text { status }\end{array}$} & \multirow[t]{2}{*}{ Treatment protocol } & \multirow{2}{*}{$\begin{array}{l}\text { Pregnancy } \\
\text { status }\end{array}$} & \multirow[t]{2}{*}{ No. } & \multicolumn{4}{|c|}{ Days from treatment/AI } \\
\hline & & & & $\begin{array}{c}\text { Total } \\
\text { cholesterol } \\
(\mathbf{m g} / \mathrm{dl})\end{array}$ & $\begin{array}{l}\text { Total } \\
\text { protein } \\
(g / d I)\end{array}$ & $\begin{array}{l}\text { Calcium } \\
(\mathrm{mg} / \mathrm{dl})\end{array}$ & $\begin{array}{c}\text { Phosphorus } \\
\text { (mg/dl) }\end{array}$ \\
\hline \multirow[t]{9}{*}{ Anestrus } & CIDR & Conceived & 6 & $129.17 \pm 5.45$ & $10.14 \pm 0.19$ & $9.08 \pm 0.18$ & $4.23 \pm 0.19$ \\
\hline & & Non-conceived & 4 & $111.06 \pm 4.04$ & $10.51 \pm 0.15$ & $9.40 \pm 0.21$ & $3.97 \pm 0.14$ \\
\hline & & Overall & 10 & $121.93 \pm 3.88^{x}$ & $10.29 \pm 0.13^{y}$ & $9.21 \pm 0.14$ & $4.12 \pm 0.13$ \\
\hline & Ovsynch & Conceived & 5 & $136.72 \pm 1.48$ & $9.30 \pm 0.19$ & $9.52 \pm 0.14$ & $4.42 \pm 0.25$ \\
\hline & & Non-conceived & 5 & $120.46 \pm 5.40$ & $10.80 \pm 0.20$ & $8.85 \pm 0.11$ & $3.84 \pm 0.09$ \\
\hline & & Overall & 10 & $128.59 \pm 3.05^{x y}$ & $9.55 \pm 0.24^{x}$ & $9.19 \pm 0.10$ & $4.13 \pm 0.14$ \\
\hline & Norgestomet ear implant & Conceived & 5 & $132.94 \pm 6.35$ & $10.37 \pm 0.15$ & $8.84 \pm 0.08$ & $3.94 \pm 0.11$ \\
\hline & & Non-conceived & 5 & $137.03 \pm 2.14$ & $10.10 \pm 0.12$ & $9.62 \pm 0.15$ & $4.05 \pm 0.09$ \\
\hline & & Overall & 10 & $134.99 \pm 3.33^{y}$ & $10.23 \pm 0.10^{y}$ & $9.23 \pm 0.11$ & $3.99 \pm 0.07$ \\
\hline \multirow[t]{3}{*}{ Normalcyclic } & Control & Conceived & 4 & $134.14 \pm 8.47$ & $10.78 \pm 0.18$ & $9.28 \pm 0.26$ & $4.75 \pm 0.31$ \\
\hline & & Non-conceived & 6 & $139.26 \pm 4.54$ & $10.97 \pm 0.21$ & $9.62 \pm 0.30$ & $4.23 \pm 0.29$ \\
\hline & & Overall & 10 & $137.78 \pm 4.36^{y}$ & $10.61 \pm 0.14^{y}$ & $9.42 \pm 0.24$ & $4.43 \pm 0.21$ \\
\hline
\end{tabular}

Means bearing uncommon superscripts within the column differ significantly between protocols $(p<0.05)$. The variations between periods and between pregnancy status were not significant in any of the groups, hence not shown here.

$\mathrm{AI}=$ Artificial insemination, $\mathrm{CIDR}=$ Controlled internal drug release

a high level of total protein had good reproductive performance.

A non-significant influence of CIDR, Ovsynch and/or Norgestomet ear implant protocols in anestrus cows and buffaloes on calcium and phosphorus levels (Table-3) as observed in the present study has also been recently documented by researchers, including normal cyclic control groups $[5,7,25,27]$. Savalia et al. [32] obtained higher mean calcium levels in conceived as compared to non-conceived buffaloes under CIDR, Ovsynch, and even normal cyclic control groups, which is in contrast to the present findings. The marginal deficiency of phosphorus is opined to be enough to cause disturbances in pituitary-ovarian axis, without manifesting specific systemic deficiency symptoms [33]. Savalia et al. [32] did not find appreciable variation in the mean plasma inorganic phosphorus levels on the day of $\mathrm{GnRH}$ and/or PG treatment, at induced estrus and on day 22 post-AI in anestrus or sub-estrus buffaloes. In the present study, the calcium concentration was non-significantly lower and inorganic phosphorus was higher in conceived than non-conceived cows. This present insignificant differences observed in plasma inorganic phosphorus profile between different phases of the cycle and even conceived and non-conceived groups corroborated with the earlier reports in dairy cows $[22,34,35]$.

\section{Conclusion}

From the results, it can be inferred that the hormonal protocols used, particularly Ovsynch and CIDR protocol, improved conception rates in anestrus crossbred cows under field conditions, and also influenced the plasma progesterone profile significantly, but not the biochemical profile, in a manner of normal cyclic animals, hence can be used by the practicing veterinarians in anestrus rural crossbred cows to improve their reproductive efficiency and thereby the farmers economy.

\section{Authors' Contributions}

AJD planned and designed the study. The experiment was conducted by AJD, BBN, KKH and JAP, while laboratory work was done by $\mathrm{BBN}, \mathrm{KKH}$ and RGS. All authors participated in data analysis, preparation of draft of the manuscript, and read and approved the same.

\section{Acknowledgments}

We gratefully acknowledge the authorities of AAU, Anand, and Amul and Panchamrut Dairies of Gujarat for providing facilities and permission granted to take up this work under their milk-shed areas and the Director of Research and Dean PG Studies, AAU, Anand for financial support.

\section{Competing Interests}

The authors declare that they have no competing interests.

\section{References}

1. Kutty, C.I. and Ramachandran, K. (2003) Bovine infertility - A field oriented categorization based on investigation among crossbred cattle in a district of Kerala. Indian $J$. Anim. Sci., 73(2): 35-37.

2. Chaudhari, C.F., Suthar, B.N., Sharma, V.K., Dabas, V.S., Chaudhari, N.F. and Panchasara, H.H. (2012) Estrus induction and fertility response in delayed pubertal Kankrej heifers treated with Norgestomet ear implant. Vet. World, 5: 453-458.

3. Savalia, K.K., Dhami, A.J., Hadiya, K.K. and Patel, K.R. (2014a) Augmenting fertility of anoestrus and repeat breeding buffaloes using controlled breeding techniques under field conditions.Indian Vet. J., 89: 23-27.

4. EL-Zarkouny, S.Z., Cartmill, J.A., Hensley, B.A. and Stevenson, J.S. (2004) Pregnancy in dairy cows after synchronized ovulation regimens with or without pre-synchronization and progesterone. J. Dairy Sci., 87: 1024-1037.

5. Nakrani, B.B., Panchal, M.T., Dhami, A.J., Hadiya, K.K., 
Patel, J.A., Gosai, R.K. and Shah, R.G. (2014) Influence of controlled breeding techniques on estrus induction response, conception rate and plasma progesterone profile in anoestrus buffaloes. Glob. J. Med. Res.,14(3): 1-6.

6. Nak, Y., Tuna, B., Nak, D., Karakas, E. and Simsek, G. (2011) The effects of Ovsynch, Ovsynch with progestin and progestin plus double TAI on pregnancy rates in unobserved oestrus dairy cows and heifers. Kafkas Univ. Vet. Fakul. Derg., 17(6): 917-922.

7. Patel, K.R., Dhami, A.J., Hadiya, K.K., Savalia, K.K. and Sarvaiya, N.P. (2013) Effect of CIDR and Ovsynch protocols on estrus response, fertility and plasma progesterone and biochemical profile in true anoestrus crossbred cows. Indian J. Anim. Prod. Mange., 29(3-4): 50-58.

8. Nath, H.C., Dutta, D.J. and Biswas, R.K. (2004) Reproductive performance of Norgestomet ear implant and PMSG administered to postpartum anoestrus cow. Indian J. Anim. Res., 38: 50-52.

9. Dhami, A.J., Panchal, M.T., Hadiya, K.K., Patel, J.A. and Shah, R.G. (2014) Use of controlled breeding techniques under field conditions for estrus synchronization and conception in anoestrus crossbred cows and buffaloes. Proceedings $2^{\text {nd }}$ Annual Meeting of SVSBT and National Seminar on Biotechnological Approaches to Challenges in Animal Health and Production.Veterinary College, DUVASU, Mathura, UP, India, March 6-7. p86.

10. Bhoraniya, H.L., Dhami, A.J., Naikoo, M., Parmar, B.C. and Sarvaiya, N.P. (2012) Effect of oestrus synchronization protocols on plasma progesterone profile and fertility in postpartum anoestrus Kankrej cows. Trop. Anim. Health Prod., 44: 1191-1197.

11. Kubasic, N.P., Hallauer, G.D. and Brodows, R.G. (1984) Evaluation of direct solid-phase RIA for progesterone, useful for monitoring luteal function. Clin. Chem., 30: 284-286.

12. Snedecor, G.W. and Cochran, W.G. (1994) Statistical Methods. 14 $4^{\text {th }}$ ed. Oxford and IBH Publishing House, New Delhi, India.

13. Rentfrow, L.R., Randel, R.D. and Neuendoeff, D.A. (1987) Effect of estrus synchronization with Syncromate- $B^{\circledR}$ on serum luteinizing hormone, progesterone and conception rate in Brahman heifers. Theriogenology, 28(3): 355-358.

14. Pinheiro, O.L., Barros, C.M., Figueiredo, R.A., DoValle, E.R., Encarnacao, R.O. and Padovani, C.R. (1998) Estrous behavior and the estrus-to-ovulation interval in Nelore cattle (Bos indicus) with natural estrus or estrus induced with prostaglandin F2 or norgestomet and estradiol valerate. Theriogenology, 49: 667-681.

15. Cavalieri, J. and Fitzpatrick, L.A. (1995) Oestrus detection techniques and insemination strategies in Bos indicus heifers synchronized with norgestomet-estradiol. Aust. Vet. J., 72(5): 177-182.

16. Ozyurtlu, N., Yunus, C., Ibrahim, K. and Mesih, K. (2009) Induction of oestrus with norgestomet ear implant and PRID in acyclic Holstein Heifers. J. Anim. Vet. Adv., 8: 1035-1039.

17. Martinez, M.C., Kastelic, J.P., Adams, G.P., Cook, B., Olson, W.O. and Mapletoft, R.J. (2002) The use of progestins in regimens for the fixed-time artificial insemination in beef cattle. Theriogenology, 57: 1049-1059.

18. Stevenson, J.S., Lamb, G.C., Johnson, S.K., MedinaBritos, M.A., Grieger, D.M., Harmoney, K.R., Cartmill, J.A., El-Zarkunoy, S.Z., Dahlen, C.R. and Marple, T.J. (2003) Supplemental norgestomet, progesterone, or melengestrol acetate increases pregnancy rates in suckled beef cows after timed inseminations. J. Anim. Sci., 81: 571-586.

19. King, M.E., Odde, K.G., LeFever, D.G., Brown, L.N. and Neubauer, C.J. (1986) Synchronization of estrus in embryo transfer recipients receiving demi-embryos with Syncromate-B or estrumate. Theriogenology, 26(2): 221-229.

20. Hixon, D.L., Kesler, D.J., Troxel, T.R., Vincent, D.L. and Wiseman, B.S. (1981) Reproductive hormone secretions and first service conception rate subsequent to ovulation control with Synchro-mate B. Theriogenology, 16(2): 219-229.

21. Singh, M., Vasishta, N.K., Sood, P. and Sharma, A. (2001) Evaluation of norgestomet, a synthetic progestogen for inducing oestrus and subsequent fertility in heifers and postpartum anoestrus cows. Indian Vet. J., 78: 961-962.

22. Ramakrishnan, A., Dhami, A.J., Naikoo, M., Parmar, B.C. and Divekar, B.S. (2012a) Estrus induction and fertility response in postpartum anoestrus Gir cows. Indian J. Anim. Reprod., 33: 37-42.

23. Naikoo, M., Patel, D.M., Sarvaiya, N.P. and Killedar, A. (2010) Estrous synchronization in postpartum anestrous Mehsana buffaloes using different hormone protocols. Indian J. Field Vet.,6(2): 1-4.

24. Ayad, A., Salaheddine, M., Touati, K., Ouada, M.I. and Benbarek, H. (2015) Evaluation of norgestomet Crestar on oestrus synchronization and reproductive performance of dairy cows in Algeria. Asian Pac. J. Reprod., 4(1): 54-60.

25. Ramakrishnan, A., Dhami, A.J., Killedar, A. and Pande, A.M. (2012b) Postpartum plasma progesterone and metabolic profile in pregnant and non-pregnant Gir cows following estrus synchronization. Indian J. Anim. Prod. Manage., 24: 40-44.

26. Savalia, K.K., Dhami, A.J., Hadiya, K.K., Patel, K.R. and Sarvaiya, N.P. (2014b) Influence of controlled breeding techniques on fertility and plasma progesterone, protein and cholesterol profile in true anoestrus and repeat breeding buffaloes. Vet. World,7(9): 727-732.

27. Srivastava, S.K. and Sahni, K.L. (2000) Blood mineral level affecting pregnancy rates in cows and buffaloes. Indian. $J$. Anim. Sci., 70: 33-34.

28. Singh, I.D., Sinha, S.N., Singh, B. and Verma, S.B. (1983) Effect of some oestrus inducing drugs on total serum cholesterol level in cattle. Indian J. Anim. Reprod., 22: 157-160.

29. Singh, M., Sharma, M. and Vasishta, N.K. (2004) Study on the use of norgestomet implants for the induction of oestrus in anoestrus heifers in the sub-temperate zone of Himachal Pradesh. Intas Polivet., 5(11): 179-182.

30. Lodhi, L.A., Qureshi, Z.I., Khan, A. and Hayat, S. (1998) Comparative study of blood glucose, total proteins, calcium and phosphorus in cycling, non-cycling, repeat breeding and endometritic buffaloes. Pak. J. Biol. Sci., 1(2): 66-68.

31. Gentile, G., Moretti, M., Gaiani, R. and Giordani, L. (1978) Correlation between some biochemical constituents and low fertility in Moderice province. Clin. Vet., 101: 17-24.

32. Savalia, K.K., Dhami, A.J., Patel, K.R. and Hadiya, K.K. (2013) Influence of controlled breeding techniques on fertility and plasma macro-minerals profile in conceived and non-conceived anestrus and repeat breeding buffaloes. Indian J. Field Vet.,9(2): 28-35.

33. Bhaskaran, R. and Abdulla Khan, C.K. (1981) Role of blood serum inorganic phosphorus in post-parturient anoestrus cows. Livest. Adv., 9(6): 33-36.

34. Mehrajuddin, A., Dhami, A.J., Ammu, R., Parmar, B.C. and Divekar, B.S. (2014) Monitoring postpartum plasma minerals profile $(\mathrm{Ca}, \mathrm{P}$ and $\mathrm{Mg})$ and fertility without and with estrus synchronization therapies at day 90 in suckled anestrous/subestrous Kankrej cows. Indian J. Field Vet., 9(4): 4-11.

35. Rowlands, G.J., Little, W. and Kitchenham, B.A. (1977) Relationships between blood composition and fertility in dairy cows - A field study. J. Dairy Res., 44: 1-7. 